\title{
KAJIAN TERJEMAHAN PENANDA KOHESI PRONOMINA DAN IDEOLOGI PENERJEMAHAN PADA HADITS ARBA'IN KE 31-40 KARYA IBNU DAQIQ AL 'IED KE DALAM BAHASA INDONESIA
}

\author{
Qonitatul Mahmudah \\ Program Studi Sastra Arab, Fakultas Ilmu Budaya, Universitas Sebelas Maret \\ Email: qonitamahmudah@gmail.com \\ Ramiz Ansharil Haq \\ Program Studi Sastra Arab, Fakultas Ilmu Budaya, Universitas Sebelas Maret \\ Email: ramizmanman@gmail.com \\ Muhammad Ridwan \\ Program Studi Sastra Arab, Fakultas Ilmu Budaya, Universitas Sebelas Maret \\ Email: muhammadridwan_fib@staff.uns.ac.id

\begin{abstract}
ABSTRAK
Hadist Arbain terdiri dari empat puluh dua hadist. Kumpulan hadist ini layak diteliti karena memiliki pengaruh yang besar di kalangan kehidupan masyarakat Islam. Hadist ini menjadi rujukan utama dalam kalangan muslim. Penelitian ini memfokuskam pada hadist nomer 31 s.d. 40, sebab hadis tersebut mengandung perintah, larangan, hukuman, dan beberapa nasihat dalam ajaran Islam. Penelitian ini menggunakan teknik deskriptif kualitatif. Metode yang digunakan adalah perbandingan. Data dalam penelitian ini adalah penanda kohesi gramatika dalam bentuk pronomina di dalam bahasa Arab dan ideologi yang terdapat dalam hadist tersebut. Penelitian ini memfokuskan pada kohesi, variasi teknik penerjemahan, metode penerjemahan, dan ideologi penerjemahan yang digunakan oleh penerjemah hadist tersebut.
\end{abstract}

Kata Kunci: hadist Arbain, kohesi, teknik, metode, ideologi

\begin{abstract}
Hadith Arba'in is a collection of the selected 42 hadiths. The name of Arba'in is taken from the amount of hadiths included in the book which is 42 hadiths. The book of hadith Arba'inis considered to be necessarily studied because this book contains the collection of the well know hadiths in islamic community awund the world. This book contains the main hadith that are very important in islamic study, started with hadith about the intention to start doing something, then followed with the basic aqidah, syari'ah, akhlak, and prophet's advice. This research specifically studies the hadiths from 31-40 because they contain suggestion, forbiddence, excellence, and some of advices about islam. This research is descriptive qualitative research. The method used is (equal/comparison) method. The data in this research are grammatical cohesion marker in the form of pronoun in Arabic language and ideological translation in the 31-40 text of hadith Arba'in written by Ibnu Daqiq Al 'ied and translated by
\end{abstract}


Muhammad Thalib. The data collection is done by taking the sample or called technique sampling. Technique of presenting data is presented by words and table of data to describe the analysis result. This reaserch investigates cohesion, variasion of translation technique, translation method, and ideological translation used by the translator in translating the expressions in the hadith.

Keywords: hadith Arba'in, cohesion, technique, method, ideology

\section{PENDAHULUAN}

Penerjemahan merupakan kegiatan yang tidak dapat dipisahkan dari perkembangan teknologi dan ilmu pengetahuan. Pada dasarnya, seorang penerjemah harus memiliki kemampuan untuk memecahkan masalah, yakni ketika seorang penerjemah tidak paham makna kata, kalimat, atau paragraf sehingga penerjemah mengalami kesulitan menerjemahkannya meskipun sudah memahami teks sumbernya. Untuk dapat menerjemahkan, seorang penerjemah harus mengetahui seluk beluk penerjemahan diantaranya prosedur, ideologi, metode dan teknik penerjemahan (Amalia 2007, h.20).

Penerjemah harus menguasai aspek-aspek bahasa dari bahasa sumber maupun bahasa sasaran. Aspek-aspek tersebut sangatlah berbeda antara bahasa sumber dengan bahasa sasaran, misalnya dalam penggunaan istilah. Penerjemah dihadapkan pada dua ideologi, yaitu foreign (asing) dan domestikasi. Penerjemah dalam menerjemahkan perlu memperhatikan terlebih dahulu jenis teks yang diterjemahkan. Jenis teks yang diangkat dalam penelitian ini adalah jenis teks agama. Teks keagamaan adalah teks yang substansinya didominasi oleh tema dan topik yang bersumber pada satu agama atau lebih (Hoed, 2006, h.33).

Buku-buku keagamaan Islam yang diimpor ke Indonesia banyak menggunakan bahasa Arab, tetapi saat proses penerjemahan ke bahasa Indonesia terjadi proses yang sama yaitu mengadopsi langsung beberapa istilah sesuai aslinya bahasa sumber atau mencari padanannya. Hasrat masyarakat untuk menggunakan buku-buku terjemahan tersebut sangat tinggi. Hal ini mendorong peneliti untuk menganalisa hasil terjemahan tersebut, terutama teknik, metode dan ideologi penerjemahan. Untuk itu, peneliti menentukan objek penelitian yang berupa teks dari kitab Arba'in Nawawi. Teks ini merupakan kumpulan dari hadits-hadits pilihan yang dirangkum oleh seorang ulama besar bermadzhab Syafi'i yang bernama Al-Imam Al-Allamah Abu Zakaria Muhyuddin bin Syaraf AnNawawi atau yang dikenal dengan Imam Nawawi.

Hadits Arba'in adalah kumpulan hadits-hadits pilihan yang berjumlah empat puluh hadits. Nama Arba'in diambil dari jumlah hadits yang terkandung dalam kitab tersebut yakni empat puluh hadits. Pengarang 
dari kitab ini adalah seorang ulama besar bermadzhab Syafi'i yang bernama Al-Imam Al-Allamah Abu Zakaria Muhyuddin bin Syaraf AnNawawi atau yang dikenal dengan Imam Nawawi. Kitab Hadits Arba'in dianggap perlu dibahas karena di dalam kitab ini merupakan kitab kumpulan hadits yang terkenal di seluruh umat Islam di dunia. Sebenarnya, ada dua kitab karangan Imam Nawawi yang sangat terkenal di dunia Islam sampai saat ini yaitu kitab Hadits Arba'in Nawawi dan kitab Riyadhus Shalihin. Selain itu, isi atau kandungan dari kitab ini merupakan hadits pokok yang sangat penting dari ajaran agama Islam beserta urutannya yang berdasarkan hal yang paling pokok. Buku itu diawali dengan hadits tentang niat yang merupakan dari awal dari mengerjakan suatu, kemudian dilanjutkan dengan dasar aqidah, syari'ah, akhlaq, dan nasihat dari Nabi.

Teknik penerjemahan merupakan suatu cara yang digunakan oleh penerjemah dalam menerjemahkan kitab Arba'in Nawawi. Selanjutnya, Al-Farisi (2011, h.61) menyatakan bahwa teknik penerjemahan merupakan cara penerjemahan kata dan frasa dengan memperhatikan konteks kalimatnya. Teknik penerjemahan merupakan penjabaran dari metode penerjemahan.

Sumarlam (2005, h.23) menyebutkan bahwa hubungan antar bagian wacana terbagi menjadi dua jenis. Hubungan itu adalah hubungan bentuk yang disebut dengan kohesi. Selanjutnya, hubungan makna atau semantis disebut dengan koherensi. Mengingat pentingnya kedudukan kohesi dalam sebuah teks, penanda kohesi patut dikaji dalam kajian penerjemahan.

Hasil penelitian ini diharapkan memberikan bermanfaat bagi akademisi penerjemahan sebagai pertimbangan dalam praktik penerjemahan. Manfaat penelitian diantaranya adalah memberikan gambaran lengkap kepada pembaca tentang penanda kohesi dan teknik penerjemahan sehingga bisa disimpulkan ideologi yang dipakai (domestikasi atau foreign-isasi) dalam terjemahan teks bahasa sasaran kitab Arba'in Nawawi. Dengan demikian, penelitian ini dapat dijadikan pertimbangan dalam menggunakan ideologi tersebut pada karya selanjutnya. Selain itu, tujuan penelitian ini memberi dukungan informasi untuk pengembangan teori dan aplikasi penerjemahan.

Karya keagamaan seperti kitab Arba'in Nawawi merupakan sebuah kitab rujukan dalam memahami fenomena keagamaan. Oleh sebab, kitab ini tentu saja dibaca dan diinterpretasikan para pembacanya. Penerjemahan dari kitab atau buku ini patut diteliti untuk menunjukkan karakteristik dan beberapa teknik penerjemahan yang dapat membantu cara menginterpretasikan dan membaca kitab ini secara tepat. Selanjutnya, dengan mengetahui 
teknik, metode, dan ideologi dari proses penerjemahan itu, kesalahan interpretasi dari teks dapat dijelaskan dari sisi linguistik atau kebahasaan.

Penjelasan secara teknik, metode, dan ideologi dapat melacak proses perahlihan simbol dan karakteristik kebudayaan dan sosial dalam bahasa yang digunakan. Hal ini sangat penting sebab penerjemahan bukan hanya bersifat pengalihan simbol bahasa ataupun kata, tetapi lebih dari itu, penerjemahan memberikan konsekuensi atas perubahan makna, transformasi kebudayaan, dan "munculnya sebuah teks yang baru". Terlepas dari keadaan itu semuan, langkah awal yang tepat untuk mengatasi berbagai kecurigaan, kesalahan, dan perubahan makna atau gagasan dalam sebuah teks, teknik, metode, dan pesan atau ideologi yang terdapat dalam penerjemahan perlu dilihat.

\section{TEORI DAN METODE PENELITIAN}

Penerjemahan merupakan pengalihan suatu teks dari bahasa yang satu (Bsu) ke bahasa lain (Bsa). Pengalihan makna ini harus ditransfer setepat-tepatnya. Sementara itu, gaya bahasa yang diterjemahkan boleh diubah sesuai dengan tujuan penerjemahan (Supana, 2012, h.16).

Teknik penerjemahan merupakan hasil dari pilihan yang dibuat oleh penerjemah. Validitas teknik bergantung pada beberapa pertanyaan yang berhubungan dengan konteks dan tujuan penerjemahan dan harapan pembaca. Menurut Molina (2002, h.510-111), teknik penerjemahan merupakan prosedur untuk menganalisis dan mengelompokkan kesepadanan makna yang tercapai dalam terjemahan. Jenis teknik penerjemahan yang digunakan dalam menerjemahkan hadits Arba'in adalah, peminjaman, penerjemahan harfiah, penambahan, dan deskripsi serta reduksi.

Peminjaman (borrowing) adalah teknik mengambil sebuah kata atau istilah langsung dari bahasa sumber. Peminjaman langsung ini disebut peminjaman murni, sedangkan peminjaman yang menggunakan penyesuaian fonetik dan morfologi bahasa sasaran adalah teknik peminjaman alamiah. Sebagai contoh adalah صاحبة sha>habah dalam bahasa Arab, menjadi sahabat dalam bahasa Indonesia. Penerjemahan harfiah (literal translation) adalah penerjemahan kata perkata atau kata demi kata. Contoh dari hal itu adalah كن fin fi> ad-dunya>, yang diterjemahkan jadilah engkau di dunia ini. Penambahan (addition) dapat dibagi menjadi dua, yaitu penambahan secara struktural dan semantis. Sebagai contohnya adalah innalla>ha katabal-chasana>ti wa-sayyia $>$ ti yang artinya "sesungguhnya Allah telah menetapkan nilai kebaikan dan kejahatan". Deskripsi (description) adalah teknik yang memberikan penjelasan atau gambaran bentuk 
dan fungsi suatu istilah dari bahasa sumber ke dalam bahasa sasaran. Contoh dari kasus ini adalah "Taqwa itu ada di sini (seraya menunjuk dada beliau tiga kali)" yaitu dengan mendeskripsikan kata التقوى ها هنا dattaqwa ha> huna> Reduksi (reduction) adalah teknik pengurangan atau penghilangan dengan tujuan memadatkan informasi dari bahasa sumber ke dalam bahasa sasaran. Contoh adalah ماء الثلج $M a>$ >'u atstsalji, yang berarti salju.

Menurut Molina (2002), metode penerjemahan merujuk pada cara melakukan suatu proses penerjemahan yang digunakan untuk mengungkapkan tujuan penerjemah, misalnya pilihan penerjemah secara umum yang mempengaruhi keseluruhan teks. Ada beberapa metode penerjemahan yang dapat digunakan dan penggunaannya tergantung pada tujuan penerjemahan tersebut. Penerjemah sering menerapkan salah satu metode penerjemahan sesuai dengan jenis teksnya. Menurut Newmmark (1998, h.45) terdapat delapan jenis metode penerjemahan seperti yang telah digambarkan dalam diagram.

\begin{tabular}{|l|r|}
\hline SL emphasis (tendensi ke bahasa sumber) & TL emphasis (tendensi ke bahasa sasaran) \\
\hline Word-for-word Translation (1) & (5) Adaptasi \\
\hline Literal Translation (2) & (6) Free Translation \\
\hline Faithful Translation (3) & (7) Idiomatic Translation \\
\hline Semantic Translation (4) & (8) Communicative Translation \\
\hline
\end{tabular}

Gambar : Diagram-V Newmark (1988, h.45)

Hatim dan Mason (1997, h.45) menagtakan bahwa translating is not a neutral activity. Dengan kata lain, penerjemahan memiliki kecenderungan-kecenderungan.

Bahkan, dalam bahasa Prancis, ada metafora yang menggambarkan penerjemahan sebagai sesuatu yang belles (cantik) dan infidêles (tidak setia), yang kemudian memunculkan ungkapan les bellesinfidêles. Bahasa Prancis menempatkan kata traduction (penerjemahan) sebagai kata yang berjenis feminine, yang oleh Hatim dan Munday (2004:104), dikatakan memiliki untrustworthy nature.
Pembahasan yang jelas tentang kecenderungan tersebut, Venuti mengajukan konsep tentang foreignizing dan domesticating. Konsep ini kemudian terkenal dengan heading ideologi dalam penerjemahan (1995,h.17-28). Dua ideologi itu berpengaruh di dua tingkat, yakni makro (menentukan teks yang perlu diterjemahkan) dan di mikro (menentukan strategi, metode, atau teknik yang digunakan dalam menerjemahkan). Pada level mikro, foreignizing adalah strategi penerjemahan dengan penerjemah mempertahankan unsur-unsur teks bahasa sumber atau 
berkecenderungan ke arah bahasa sumber (SL emphasize).

Berbeda dengan foreignizing, domesticating merupakan cara penerjemahan dengan menyesuaikan unsur yang ada dalam teks bahasa sumber dengan keadaan bahasa sasaran (TL emphasize). Cara ini menghasilkan "an ethnocentric reduction of the foreign text to target language cultural values" dan "bring the author back home". Penerjemah yang beraliran ini berpendapat bahwa komponen esensial dari suatu karya bukanlah sisi-sisi yang bersifat teknis, melainkan spiritnya. Strategi ini juga disebut target language approach atau author-to-reader approach. Ideologi ini menyakini bahwa penerjemah yang berterima adalah yang sesuai dengan selera pembaca yang menginginkan teks terjemahan dan sesuai dengan kebudayaan masyarakat bahasa sasaran. Dengan kata lain, suatu karya terjemahan tidak terasa seperti terjemahan. Terkait dengan diagram $\mathrm{V}$ dari Newmark, biasanya, metode yang dipilih adalah metode yang berorientasi pada bahasa sasaran seperti, adaptasi, penerjemahan idiomatik, dan penerjemahan komunikatif.

Kohesi adalah hubungan antar bagian dalam teks yang ditandai penggunaan unsur bahasa. Penanda kohesi adalah ciri yang menunjukkan adanya hubungan antar bagian dalam sebuah teks. Kohesi dibagi menjadi dua jenis, yaitu kohesi gramatikal dan kohesi leksikal. Jenis kohesi gramatikal dibedakan menjadi empat, yaitu pengacuan (referensi), penyulihan (substitusi), pelesapan (elipsis), dan perangkaian (konjungsi). Kohesi gramatikal pengacuan dibagi menjadi tiga, yaitu pengacuan persona, pengacuan demonstratif, dan pengacuan komparatif.

Sumarlam (2005: 23-24) membagi pengacuan menjadi dua jenis berdasarkan tempat dan berdasarkan arah pengacuannya. Berdasarkan tempat, pengacuan dibagi menjadi dua macam, yaitu pengacuan endofora (apabila acuannya berada di dalam teks wacana) dan pengacuan eksofora (apabila acuannya berada di luar teks wacana). Berdasarkan arah pengacuannya, hal ini dibedakan menjadi dua, yaitu anaforis dan kataforis. Satuan lingual tertentu pada satuan lingual lain dapat berupa persona (kata ganti orang), demonstratif (kata ganti petunjuk), dan komparatif (satuan lingual yang berfungsi untuk membandingkan antar unsur). Penelitian ini memfokuskan kohesi gramatikal pengacuan persona.

Nomina, baik yang menyatakan orang dan hewan atau kebendaan seringkali digantikan kedudukannya dalam kalimat dengan bentuk kata lain. Hal ini lazimnya disebut pronomina (kata ganti atau Adhdhamir). Berdasarkan peran sebagai pelaku dalam kalimat, hal iu dibedakan menjadi tiga macam yakni orang pertama (منك mutakallim: 
Qonitatul Mahmudah, dkk - Kajian Terjemahan Penanda Kohesi Pronomina dan Ideologi Penerjemahan pada Hadits Arba'in ke 31-40 Karya Ibnu Daqiq Al-ied ke dalam Bahasa Indonesia

menggantikan diri orang yang berbicara, أناana> : aku, saya, dan tunggal, dan نحنnahnu: kami, kota, "saya/aku" untuk mengagungkan diri, jamak), orang kedua (مخاطب) mukha>thab, kata yang menggantikan diri orang yang diajak bicara). Berikut ini adalah yang termasuk kata ganti orang kedua.

\begin{tabular}{|c|c|}
\hline أنتَanta : kamu, anda (tunggal lk) & أنتِ \\
\hline أنتما : Kalian, anda (dobel lk/pr) & أنتنّ : kamu sekalian (jamak pr) \\
\hline أنتم : kamu, kalian (jamak lk) & \\
\hline
\end{tabular}

Selanjutnya adalah kata ganti orang ketiga (غائب), yaitu kata yang dibicarakan. Kata ganti orang ketiga menggantikan diri orang yang diantaranya adalah sebagai berikut.

\begin{tabular}{|l|l|l|}
\hline ه : ia, dia (tunggal laki-laki) & \multicolumn{2}{|c|}{ : ia, dia (tunggal perempuan) } \\
\hline Lه : mereka berdua (ganda & $\begin{array}{l}\text { ه : mereka semua (jamak } \\
\text { laki/perempuan) }\end{array}$ & \multicolumn{2}{|l}{} \\
\hline ه : mereka semua (jamak laki) & & \\
\hline
\end{tabular}

Pronomina dalam percaturan kalimat mengalami perubahan bentuk. Bentuk dan pemakaiannya adalah sebagai berikut.

\section{Pengacuan Pronomina BSu}

\begin{tabular}{|c|c|c|c|c|}
\hline متّصل III & مثّصل II & I منفصل I & Ket & erangan \\
\hline ى ني & تُ & أنا & \multirow{2}{*}{\multicolumn{2}{|c|}{ Ke. I }} \\
\hline نا & ناً & نحن & & \\
\hline ك & تَ & أنتًَ & \multirow{3}{*}{ Laki-laki } & \multirow{6}{*}{ Ke. II } \\
\hline كَكَا & تُمَاً & أنتما & & \\
\hline كُمْ & نُّْ & أنتم & & \\
\hline كَِ & $ت$ & أنتتِ & \multirow{3}{*}{ Perempuan } & \\
\hline كُمَا & تما & أنتما & & \\
\hline كُمَا & تنّ & أننّ & & \\
\hline 0 & Tidak ada & هو & \multirow{3}{*}{ Laki-laki } & \multirow{6}{*}{ Ke. III } \\
\hline هُمَا & 1 & هol & & \\
\hline هُهْ & و واو & هم & & \\
\hline هَا & تُ & هي & \multirow{3}{*}{ Perempuan } & \\
\hline هُمَا & نَا & Lo & & \\
\hline هُنَّ & نَ & هنّ & & \\
\hline
\end{tabular}




\section{Keterangan:}

I. Munfashil, bentuk mandiri (bentuk asal)

II. Muttashil, bentuk tersambung verba madhi menjadi fa'il atau na'ib fa'il

III. Muttashil, bentuk tersambung menjadi maf'ul bih, mudhaf ilaih, dan al-majrur (dengan preposisi)

Sumarlam (2003, h.24-25) membuat

klasifikasi pengacuan pronomina

dalam bahasa Indonesia sebagai

berikut.

\section{Pengacuan Pronomina BSa}

\begin{tabular}{|l|ll|}
\hline Persona I & a. $\begin{array}{l}\text { Tunggal: aku, saya, hamba, gua/gue, ana/ane } \\
\text { Terikat lekat kiri: ku- } \\
\text { Terikat lekat kanan: -ku }\end{array}$ \\
& b. & Jamak: kami, kita \\
\hline Persona 2 & a. $\begin{array}{l}\text { Tunggal: kamu, anda, kau, saudara } \\
\text { Terikat lekat kiri: kau- } \\
\text { Terikat lekat kanan: -mu }\end{array}$ \\
& b. & Jamak: kalian, kamu semua, anda semua \\
\hline Persona 3 & a. $\begin{array}{l}\text { Tunggal: dia, ia, beliau } \\
\text { Terikat lekat kiri: dia- } \\
\text { Terikat lekat kanan: -nya }\end{array}$ \\
& b. Jamak: mereka \\
\hline
\end{tabular}

Pronomina dalam bahasa Arab (Bsu) dan pronomina dalam bahasa Indonesia (Bsa), sebagaimana tampak dalam bagan pronomina dalam bahasa Arab dan bahasa Indonesia, memiliki beberapa perbedaan. Bsu dibedakan antara pronomina persona tunggal laki-laki dan pronomina persona tunggal perempuan sedangkan dalam Bsa tidak dibedakan. Pronomina persona orang kedua tunggal laki-laki dalam bahasa Arab adalah أنــن sedangkan pronomina persona orang kedua tunggal perempuan dalam bahasa Arab adalah أنت . Pronomina persona

dalam Bsa tidak ada perbedaan semacam ini.
Data dalam penelitian ini adalah penanda kohesi gramatikal bentuk pronomina dalam bahasa Arab. Sumber satuan lingual ini diambil dari sumber data teks hadits Arba'in ke 31-40 karya Ibnu Daqiq Al 'Ied yang diterjemahkan oleh Muhammad Thalib, 2001 oleh penerbit Media Hidayah Yogyakarta. Penelitian ini diarahkan pada setiap penanda kohesi pronomina dan kajian teknik penerjemahan, metode penerjemahan dan ideologi pada setiap hadits.

Pengumpulan data diawali dengan pengambilan sampel atau disebut dengan teknik sampling. Marzuki (1982, h.41) menjelaskan bahwa teknik sampling hanyalah 
mencatat sebagian dari objek, gejala atau peristiwa, atau tidak seluruhnya. Langkah berikutnya dilakukan teknik simak catat. Pencatatan data dilakukan dengan cara membaca beberapa sub judul dalam teks bahasa sumber kemudian menyesuaikan teks bahasa sasaran. Setelah membandingkan hasil kemudian mencatat kata-kata yang berupa pronomina dalam bahasa Arab. Dari beberapa data pronomina yang terkumpul tersebut, langkah berikutnya dilakukan pencatatan. Pencatatan dilakukan dengan memilih sebagian data saja dan tidak semua data dimasukkan.

Metode yang digunakan dalam analisis data penelitian ini adalah metode padan. Metode padan adalah metode analisis data yang alat penentunya berada di luar, terlepas, dan tidak menjadi bagian dari bahasa yang bersangkutan atau yang diteliti (Kesuma, 2007, h.47). Penyajian hasil analisis pada penelitian penerjemahan penanda kohesi dalam teks hadits Arba'in ke 31-40 karya Ibnu Daqiq Al 'Ied dilakukan secara informal, yakni data disajikan dengan kata-kata dan tabel data untuk mendeskripsikan hasil analisis.

Selanjutnya, tahap pertama penelitian adalah pengkajian dokumen terhadap buku subjek. Analisis mengenai penanda kohesi pengacuan persona yang direalisasikan melalui pronomina persona, teknik penerjemahan, metode penerjemahan, didasarkan pada satuan pronomina. Keseluruhan data dianalisis pronomina kohesi dan teknik yang digunakan. Dari langkah tersebut, hasilnya adalah merumuskan metode dan ideologi penerjemahan yang dipakai.

HASIL DAN PEMBAHASAN

Teknik, Metode, dan Ideologi Terjemahan pada Hadist 31

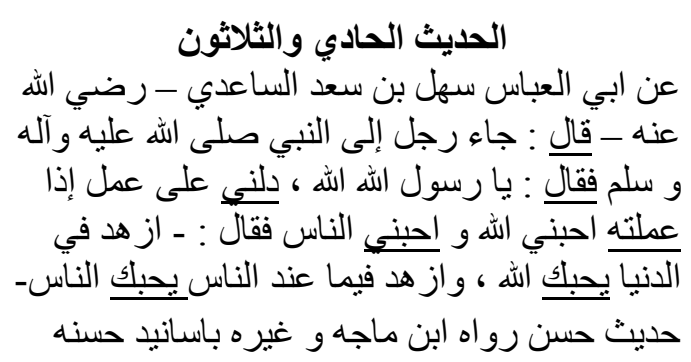

\section{Terjemahan:}

Dari Abu 'Abbas Sahl bin Sa'ad As-Sa'idi radhiallahu 'anhu, ia berkata: "Seorang laki-laki datang kepada Nabi Shallallahu 'alaihi wa Sallam lalu berkata: 'Wahai Rasulullah, tunjukkanlah kepadaku suatu perbuatan yang jika aku mengerjakannya, maka aku dicintai Allah dan dicintai manusia'. Maka sabda Beliau :Zuhudlah engkau pada dunia, pasti Allah mencintaimu dan zuhudlah engkau pada apa yang dicintai manusia, pasti manusia mencintaimu". (HR. Ibnu Majah dan yang lainnya, hadits hasan) 


\begin{tabular}{|c|c|c|c|}
\hline $\begin{array}{c}\text { Teks bahasa } \\
\text { sumber }\end{array}$ & $\begin{array}{c}\text { Penanda } \\
\text { Kohesi }\end{array}$ & $\begin{array}{c}\text { Teks bahasa } \\
\text { sasaran }\end{array}$ & Analisis Penanda kohesi pronominal \\
\hline 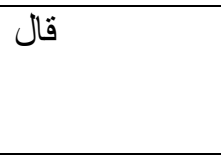 & $\begin{array}{l}\text { os dhamir } \\
\text { muttasil } \\
\text { mustatir }\end{array}$ & ia & $\begin{array}{l}\text { ه mengacu pada Abu 'Abbas kata ganti } \\
\text { tunggal \&, dhamir muttasil mustatir, } \\
\text { persona } 3\end{array}$ \\
\hline 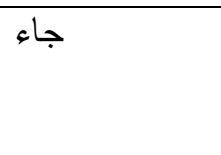 & $\begin{array}{l}\text { o dhamir } \\
\text { muttasil } \\
\text { mustatir }\end{array}$ & Datang & $\begin{array}{l}\text { جاء mengacu pada kata ganti tunggal } \\
\text { dhamir muttasil mustatir, persona } 3 \\
\text { yaitu mengacu pada seorang laki-laki }\end{array}$ \\
\hline فقال & $\begin{array}{l}\text { os dhamir } \\
\text { muttasil } \\
\text { mustatir }\end{array}$ & Berkata & $\begin{array}{l}\text { فقال mengacu pada seorang laki-laki kata } \\
\text { ganti tunggal ه, dhamir muttasil } \\
\text { mustatir, persona } 3\end{array}$ \\
\hline دلني & ي & $\mathrm{Ku}$ & $\begin{array}{l}\text { mengacu pada seorang laki-laki, kata } \\
\text { ganti tunggal أنا, dhamir muttasil baris, } \\
\text { persona } 1\end{array}$ \\
\hline عملته & $ت$ & Nya & $\begin{array}{l}\text { أنت mengacu pada kata ganti tunggal, } \\
\text { dhamir muttasil baris, persona } 2 \text { dan } \\
\text { mengacu pada suatu pekerjaan, kata } \\
\text { ganti tunggal ه , dhamir muttasil baris, } \\
\text { persona } 3\end{array}$ \\
\hline احبني & ي & Aku & $\begin{array}{l}\text { يmengacu pada seorang laki-laki, kata } \\
\text { ganti tunggal أنا, dhamir muttasil baris, } \\
\text { persona } 1\end{array}$ \\
\hline يحبك & ي & - & $\begin{array}{l}\text { ي mengacu pada Allah kata ganti tunggal } \\
\text { هو, dhamir muttasil baris, persona } 3\end{array}$ \\
\hline يحبك & ك & $\mathrm{Mu}$ & $\begin{array}{l}\text { S mengacu pada seorang laki-laki kata } \\
\text { ganti tunggal أنت, dhamir muttasil baris, } \\
\text { persona } 2\end{array}$ \\
\hline
\end{tabular}

Data tersebut merupakan data yang menggunakan pengacuan persona yang direalisasikan melalui pronomina persona. Hadits ke 31 ini menggunakan teknik peminjaman yang dinaturalisasi, yakni pada kata " ازهد" izhad, yang artinya zuhudlah. Metode penerjemahan yang digunakan adalah metode harfiah sehingga ideologi yang digunakan adalah ideologi foreign-isasi.
Teknik, Metode, dan Ideologi Terjemahan pada Hadits 32

$$
\begin{aligned}
& \text { الحديث الثاني والثلاثون } \\
& \text { عن أبى سعيد - سعد بن مالتك بن سنان- الخدري }
\end{aligned}
$$

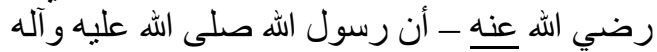

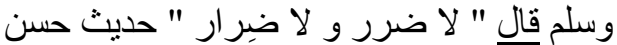

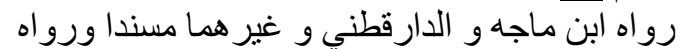

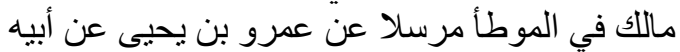

$$
\begin{aligned}
& \text { عن النبي صلى الله عليه وسلم فأسقط أبا سعيد ، وله بله } \\
& \text { طرق أخرى يقوي بعضىها بعضا }
\end{aligned}
$$


"Janganlah engkau membahayakan dan saling merugikan”. (HR. Ibnu Majah, Daraquthni dan lain-lainnya, hadits hasan. Hadits ini juga diriwayatkan oleh Imam Malik dalam Al Muwaththa sebagai hadits mursal dari Amr bin Yahya dari bapaknya dari Nabi Shallallahu 'alaihi wa Sallam tanpa menyebut Abu Sa'id. Hadits ini mempunyai beberapa jalan yang saling menguatkan)

\begin{tabular}{|c|c|c|c|}
\hline $\begin{array}{c}\text { Teks } \\
\text { bahasa } \\
\text { sumber }\end{array}$ & $\begin{array}{c}\text { Penanda } \\
\text { kohesi }\end{array}$ & $\begin{array}{c}\text { Teks } \\
\text { bahasa } \\
\text { sasaran }\end{array}$ & Analisis Penanda kohesi pronomina \\
\hline عنده & o & Anhu & $\begin{array}{l}\text { - mengacu pada Abu Sa'id kata ganti } \\
\text { tunggal هو, dhamir muttasil baris, } \\
\text { persona } 3\end{array}$ \\
\hline قال & $\begin{array}{l}\text { o dhamir } \\
\text { muttasil } \\
\text { mustatir }\end{array}$ & Bersabda & $\begin{array}{l}\text { قال mengacu pada Rasulullah, kata ganti } \\
\text { tunggal هو, dhamir muttasil mustatir, } \\
\text { persona } 3\end{array}$ \\
\hline لا ضرر & أنت & Engkau & $\begin{array}{l}\text { Terjemahan kata engkau mengacu pada } \\
\text { kata أنت ضرر mengacu pada kata ganti } \\
\text { tunggal dhamir muttasil baris, } \\
\text { persona 2 }\end{array}$ \\
\hline
\end{tabular}

Data tersebut merupakan data yang menggunakan pengacuan persona yang direalisasikan melalui pronomina persona. Teks tersebut menggunakan teknik penerjemahan penambahan secara struktural. Hal ini ditunjukkan dengan penggunana kata "engkau" dan "saling". Penambahan ini dilakukan agar struktur bahasa sasaran dapat diterima pembaca. Selain itu, tujuan utamanya adalah agar dapat dipahami dengan jelas. Penerjemahan teks tersebut menggunakan metode penerjemahan komunikatif. Hal ini dikarena mengutamakan pesan dalam teks tersebut. Teks tersebut menggunakan ideologi domestikasi.
Teknik, Metode, dan Ideologi Terjemahan Hadits 33

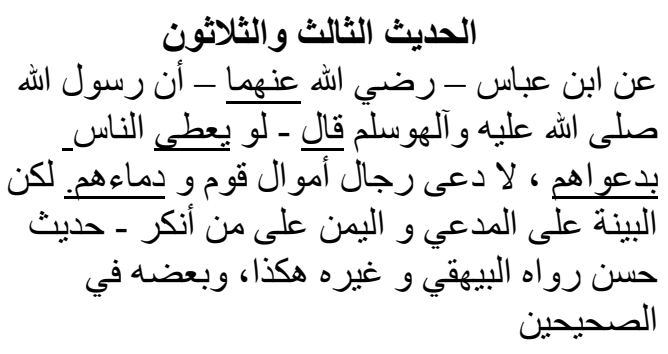

\section{Terjemahan:}

Dari Ibnu 'Abbas radhiallahu 'anhu, sesungguhnya Rasulullah shallallahu 'alaihi wa sallam telah bersabda: "Sekiranya setiap tuntutan orang dikabulkan begitu saja, niscaya orangorang akan menuntut darah orang lain atau hartanya. Akan tetapi, haruslah ada bukti atau saksi bagi yang menuntut dan bersumpah bagi yang mengingkari (dakwaan)".

(HR. Baihaqi, hadits Hasan, sebagian lafazhnya ada pada riwayat Bukhari dan Muslim) 


\begin{tabular}{|c|c|c|c|}
\hline $\begin{array}{c}\text { Teks } \\
\text { bahasa } \\
\text { sumber }\end{array}$ & $\begin{array}{c}\text { Penanda } \\
\text { kohesi }\end{array}$ & $\begin{array}{l}\text { Teks bahasa } \\
\text { sasaran }\end{array}$ & Analisis Penanda kohesi pronomina \\
\hline عنهما & 。 & 'anhu & $\begin{array}{l}\text { L mengacu pada kata ganti tunggal Lo, } \\
\text { dhamir muttasil baris, persona } 3 \text { yaitu } \\
\text { Ibnu 'Abbas }\end{array}$ \\
\hline قال & $\begin{array}{l}\text { dhamir } \\
\text { muttasil } \\
\text { mustatir }\end{array}$ & - & $\begin{array}{l}\text { قال mengacu pada Rasulullah, kata ganti } \\
\text { tunggal هو, dhamir muttasil mustatir, } \\
\text { persona } 3\end{array}$ \\
\hline يعطى & ي & dikabulkan & $\begin{array}{l}\text { يعطى mengacu pada kata ganti tunggal هو, } \\
\text { dhamir muttasil baris, persona } 3\end{array}$ \\
\hline بدعواهم & هم & setiap tuntutan & $\begin{array}{l}\text { \&engacu pada setiap tuntutan orang, } \\
\text { kata ganti jamak } \curvearrowright \text {, dhamir muttasil baris, } \\
\text { persona } 3\end{array}$ \\
\hline دماءهم & هم & $\begin{array}{l}\text { darah orang } \\
\text { lain }\end{array}$ & $\begin{array}{l}\text { دماءه mengacu pada kata ganti jamak } \\
\text { dhamir muttasil baris, persona } 3\end{array}$ \\
\hline
\end{tabular}

Data tersebut merupakan data yang menggunakan pengacuan persona yang direalisasikan melalui pronomina persona. Penerjemahan hadits tersebut menggunakan teknik penerjemahan literal. Metode penerjemahan berorientasi pada bahasa sumber, yaitu metode kata demi kata. Teks tersebut dapat dikatakan menggunakan ideologi foreign-isasi.
Teknik, Metode, dan Ideologi Terjemahan pada Hadits 34

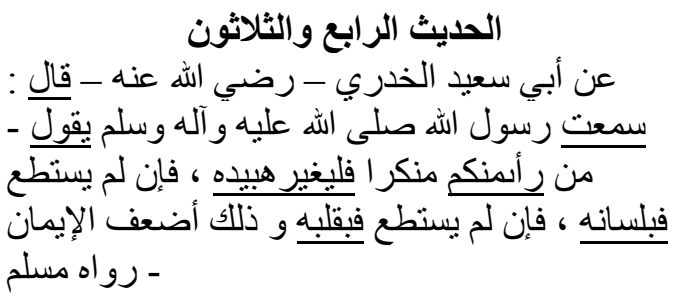

Terjemahan: Dari Abu Sa'id Al Khudri radhiyallahu anhu, ia berkata: Aku mendengar Rasulullah shallallahu 'alaihi wa sallam bersabda: "Barang siapa di antaramu melihat kemungkaran, hendaklah ia merubahnya (mencegahnya) dengan tangannya (kekuasaannya); jika ia tak sanggup, maka dengan lidahnya (menasihatinya); dan jika tak sanggup juga, maka dengan hatinya (merasa tidak senang dan tidak setuju), dan demikian itu adalah selemah-lemah iman". (HR.Muslim) 


\begin{tabular}{|c|c|c|c|}
\hline $\begin{array}{l}\text { Teks } \\
\text { bahasa } \\
\text { sumber }\end{array}$ & $\begin{array}{l}\text { Penanda } \\
\text { kohesi }\end{array}$ & $\begin{array}{l}\text { Teks } \\
\text { bahasa } \\
\text { sasaran } \\
\end{array}$ & Analisis Penanda kohesi pronomina \\
\hline عنه ( قا & ○ & 'anhu & $\begin{array}{l}\text { - mengacu pada Abu Sa'id Al Khudri, kata } \\
\text { ganti tunggal هو, dhamir muttasil baris, } \\
\text { persona } 3\end{array}$ \\
\hline قال & $\begin{array}{l}\text { dhamir } \\
\text { muttasil } \\
\text { mustatir }\end{array}$ & ia berkata & $\begin{array}{l}\text { قال mengacu pada Abu Sa'id Al Khudri, kata } \\
\text { ganti tunggal هو, dhamir muttasil mustatir, } \\
\text { persona } 3\end{array}$ \\
\hline | لمعت & $ت$ & Aku & $\begin{array}{l}- \text { mengacu pada Abu Sa'id Al Khudri kata } \\
\text { ganti tunggal أنا, dhamir muttasil baris, } \\
\text { persona } 1\end{array}$ \\
\hline يقول & ي & - & $\begin{array}{l}\text { mengacu pada Rasulullah, kata ganti } \\
\text { tunggal ه dhamir muttasil baris, persona } 3\end{array}$ \\
\hline 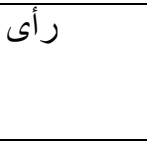 & $\begin{array}{l}\text { o dhamir } \\
\text { muttasil } \\
\text { mustatir }\end{array}$ & - & $\begin{array}{l}\text { رأى mengacu padakata ganti tunggal } \\
\text { dhamir muttasil mustatir, persona } 3\end{array}$ \\
\hline منكم & ك & Antaramu & $\begin{array}{l}\text { أنتم } \text { mengacu pada kata ganti jamak } \\
\text { dhamir muttasil baris, persona } 2\end{array}$ \\
\hline فليِغيره & ي & Nya & $\begin{array}{l}\text { ه mengacu pada kata ganti tunggal } \\
\text { dhamir muttasil baris, persona } 3 \\
\text { ه mengacu pada kata ganti tunggal } \\
\text { dhamir muttasil baris, persona } 3\end{array}$ \\
\hline بيده & o & Nya & $\begin{array}{l}\text { mengacu pada kata ganti tunggal } \\
\text { dhamir muttasil baris, persona } 3\end{array}$ \\
\hline 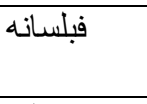 & o & Nya & $\begin{array}{l}\text { - mengacu pada kata ganti tunggal ه ه } \\
\text { dhamir muttasil baris, persona } 3\end{array}$ \\
\hline 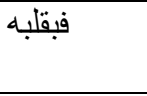 & o & Nya & $\begin{array}{l}\text { - mengacu pada kata ganti tunggal } \\
\text { dhamir muttasil baris, persona } 3\end{array}$ \\
\hline لم يستطع & ي & ia & $\begin{array}{l}\text { ي mengacu pada kata ganti tunggal } \\
\text { dhamir muttasil baris, persona } 3\end{array}$ \\
\hline
\end{tabular}

Data tersebut merupakan data yang menggunakan pengacuan persona yang direalisasikan melalui pronomina persona. Penerjemahan menggunakan teknik peminjaman yang dinaturalisasi. Kata diterjemahkan menjadi "kemungkaran". Terjemahan menggunakan metode penerjemahan literal sehingga termasuk ideologi foreignisasi.
Teknik, Metode, dan Ideologi Terjemahan pada Hadits 35

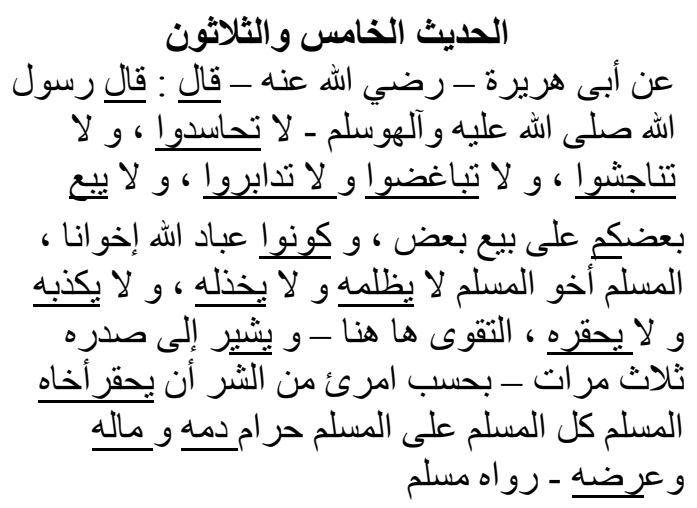




\section{Terjemahan}

Dari Abu Hurairah radhiallahu 'anhu, ia berkata: "Rasulullah shallallahu 'alaihi wa sallam bersabda: "Kamu sekalian, satu sama lain \anganlah saling mendengki, saling menipu, saling membenci, saling menjauhi dan janganlah membeli barang yang sedang ditawar orang lain. Dan jadilah kamu sekalian hamba-hamba Allah yang bersaudara. Seorang muslim itu adalah saudara bagi muslim yang lain, maka tidak boleh menzhaliminya, menelantarkannya, mendustainya dan menghinakannya. Taqwa itu ada di sini (seraya menunjuk dada beliau tiga kali). Seseorang telah dikatakan berbuat jahat jika ia menghina saudaranya sesama muslim. Setiap muslim haram darahnya bagi muslim yang lain, demikian juga harta dan kehormatannya". (HR.Muslim)

\begin{tabular}{|c|c|c|c|}
\hline $\begin{array}{l}\text { Teks } \\
\text { bahasa } \\
\text { sumber }\end{array}$ & $\begin{array}{c}\text { Penanda } \\
\text { kohesi }\end{array}$ & $\begin{array}{c}\text { Teks } \\
\text { bahasa } \\
\text { sasaran }\end{array}$ & Analisis Penanda kohesi pronominal \\
\hline قال & $\begin{array}{l}\text { ه dhamir } \\
\text { muttasil } \\
\text { mustatir }\end{array}$ & ia & $\begin{array}{l}\text { قال mengacu pada Abu Hurairah, kata } \\
\text { ganti tunggal ه, dhamir muttasil } \\
\text { mustatir, persona } 3\end{array}$ \\
\hline قال & $\begin{array}{l}\text { o dhamir } \\
\text { muttasil } \\
\text { mustatir }\end{array}$ & Bersabda & $\begin{array}{l}\text { قال mengacu pada Rasulullah, kata } \\
\text { ganti tunggal ه, dhamir muttasil } \\
\text { mustatir, persona } 3\end{array}$ \\
\hline لا تحاسدوا & و واو & - & $\begin{array}{l}\text { واو mengacu pada "kamu sekalian" } \\
\text { kata ganti jamak ه, dhamir muttasil } \\
\text { baris, persona } 3\end{array}$ \\
\hline لا تناجشوا & واو & - & $\begin{array}{l}\text { واو mengacu pada "kamu sekalian" } \\
\text { kata ganti jamak ه, dhamir muttasil } \\
\text { baris, persona } 3\end{array}$ \\
\hline لا تباغضوا & واو & - & $\begin{array}{l}\text { واو mengacu pada "kamu sekalian" } \\
\text { kata ganti jamak ه, dhamir muttasil } \\
\text { baris, persona } 3\end{array}$ \\
\hline لا تدابروا & واو & - & $\begin{array}{l}\text { واو mengacu pada "kamu sekalian" } \\
\text { kata ganti jamak ه, dhamir muttasil } \\
\text { baris, persona } 3\end{array}$ \\
\hline ي يع بعضكم & كم & - & $\begin{array}{l}\text { s mengacu pada "kamu sekalian" kata } \\
\text { ganti tunggal ه, dhamir muttasil } \\
\text { baris, persona } 3 \\
\text { ك mengacu pada "sebagian dari } \\
\text { kalian" kata ganti jamak أنت , dhamir } \\
\text { muttasil baris, persona } 2\end{array}$ \\
\hline كونوا & واو & $\begin{array}{l}\text { kamu } \\
\text { sekalian }\end{array}$ & $\begin{array}{l}\text { واو mengacu pada "kamu sekalian" } \\
\text { kata ganti jamak ه, dhamir muttasil } \\
\text { baris, persona } 3\end{array}$ \\
\hline لا يظلمه & ي & Nya & $\begin{array}{l}\text { mengacu pada seorang muslim, kata } \\
\text { ganti tunggal ه, dhamir muttasil } \\
\text { baris, persona } 3 \\
\text { ه mengacu pada saudara semuslim, } \\
\text { kata ganti tunggal ه ه dhamir muttasil } \\
\text { baris, persona } 3\end{array}$ \\
\hline
\end{tabular}


Qonitatul Mahmudah, dkk - Kajian Terjemahan Penanda Kohesi Pronomina dan Ideologi Penerjemahan pada Hadits Arba'in ke 31-40 Karya Ibnu Daqiq Al-ied ke dalam Bahasa Indonesia

\begin{tabular}{|c|c|c|c|}
\hline $\begin{array}{c}\text { Teks } \\
\text { bahasa } \\
\text { sumber }\end{array}$ & $\begin{array}{c}\text { Penanda } \\
\text { kohesi }\end{array}$ & $\begin{array}{c}\text { Teks } \\
\text { bahasa } \\
\text { sasaran }\end{array}$ & Analisis Penanda kohesi pronominal \\
\hline ل الا يخذله & ي & Nya & $\begin{array}{l}\text { smengacu pada seorang muslim, kata } \\
\text { ganti tunggal هو, dhamir muttasil } \\
\text { baris, persona } 3 \\
\text { o mengacu pada saudara semuslim } \\
\text { kata ganti tunggal هو, dhamir muttasil } \\
\text { baris, persona } 3\end{array}$ \\
\hline لا يكذبه & ي & Nya & $\begin{array}{l}\text { smengacu pada seorang muslim, kata } \\
\text { ganti tunggal ه, dhamir muttasil } \\
\text { baris, persona } 3 \\
\text { ه mengacu pada saudara semuslim } \\
\text { kata ganti tunggal ه dhamir muttasil } \\
\text { baris, persona } 3\end{array}$ \\
\hline لا يحقره & ي & Nya & $\begin{array}{l}\text { s mengacu pada seorang muslim, kata } \\
\text { ganti tunggal ه, dhamir muttasil } \\
\text { baris, persona } 3 \\
\text { ه mengacu pada saudara semuslim, } \\
\text { kata ganti tunggal ه dhamir muttasil } \\
\text { baris, persona } 3\end{array}$ \\
\hline التقوى ها & ها & - & $\begin{array}{l}\text { ه mengacu pada kata ganti tunggal } \\
\text { هي, dhamir muttasil baris, persona } 3\end{array}$ \\
\hline 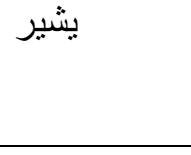 & ي & - & $\begin{array}{l}\text { mengacu pada Rasulullah, kata } \\
\text { ganti tunggal ه, dhamir muttasil } \\
\text { baris, persona } 3\end{array}$ \\
\hline يحقر & ي & ia & $\begin{array}{l}\text { s mengacu pada seseorang, kata ganti } \\
\text { tunggal ه ه, dhamir muttasil baris, } \\
\text { persona } 3\end{array}$ \\
\hline أخاه & o & Nya & $\begin{array}{l}\text { - mengacu pada saudara semuslim, } \\
\text { kata ganti tunggal ه , dhamir muttasil } \\
\text { baris, persona } 3\end{array}$ \\
\hline 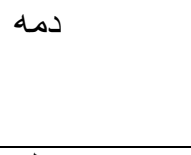 & $\circ$ & Nya & $\begin{array}{l}\text { - mengacu pada setiap muslim, kata } \\
\text { ganti tunggal ه, dhamir muttasil } \\
\text { baris, persona } 3\end{array}$ \\
\hline و م ماله & $\circ$ & juga & $\begin{array}{l}\text { - mengacu pada setiap muslim, kata } \\
\text { ganti tunggal هو dhamir muttasil } \\
\text { baris, persona } 3\end{array}$ \\
\hline 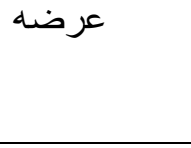 & o & Nya & $\begin{array}{l}\text { - mengacu pada setiap muslim, kata } \\
\text { ganti tunggal ه ه dhamir muttasil } \\
\text { baris, persona } 3\end{array}$ \\
\hline
\end{tabular}

Data tersebut merupakan data yang menggunakan pengacuan persona yang direalisasikan melalui pronomina persona. Penerjemahan menggunakan teknik deskripsi pada kata. Kutipan menyebutkan bahwa "Taqwa itu ada di sini (seraya menunjuk dada beliau tiga kali)". Hal 
itu mendeskripsikan kata التقوى ها Lisat-taqwa ha> huna>, untuk memberikan gambaran bahwa yang dimaksud di sini adalah di dada. Penerjemahan menggunakan metode penerjemahan bebas sehingga terlihat ideologi yang digunakan yaitu ideologi domestikasi.

Teknik, Metode, dan Terjemahan pada Hadits 36

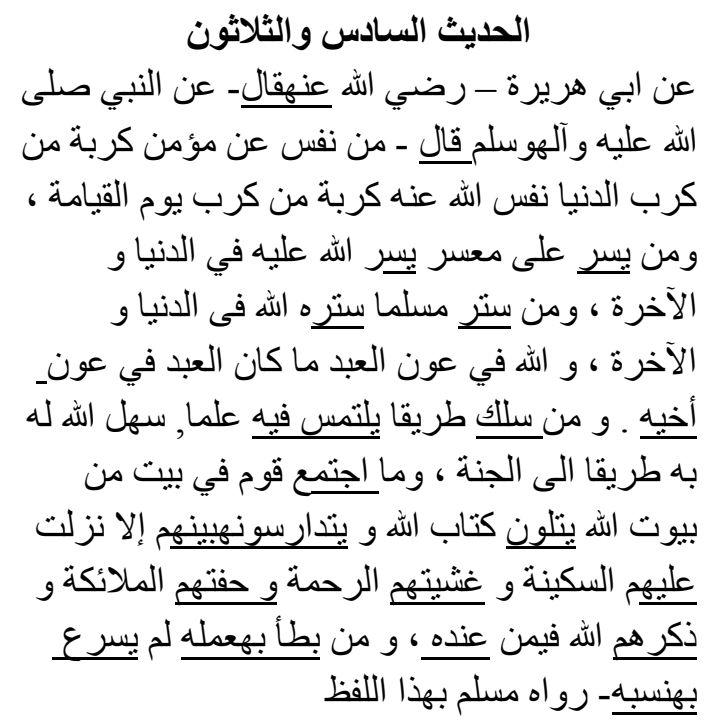

\section{Terjemahan:}

Dari Abu Hurairah radhiallahu 'anhu dari Nabi shallallahu 'alaihi wa sallam, Beliau bersabda: "Barang siapa yang melepaskan satu kesusahan seorang mukmin, pasti Allah akan melepaskan darinya satu kesusahan pada hari kiamat. Barang siapa yang menjadikan mudah urusan orang lain, pasti Allah akan memudahkannya di dunia dan di akhirat. Barang siapa yang menutup aib seorang muslim, pasti Allah akan menutupi aibnya di dunia dan di akhirat. Allah senantiasa menolong hamba-Nya selama hamba-Nya itu suka menolong saudaranya. Barang siapa menempuh suatu jalan untuk mencari ilmu, pasti Allah memudahkan baginya jalan ke surga. Apabila berkumpul suatu kaum di salah satu masjid untuk membaca $\mathrm{Al}$ Qur'an secara bergantian dan mempelajarinya, niscaya mereka akan diliputi sakinah (ketenangan), diliputi rahmat, dan dinaungi malaikat, dan Allah menyebut nama-nama mereka di hadapan makhluk-makhluk lain di sisiNya. Barangsiapa yang lambat amalannya, maka tidak akan dipercepat kenaikan derajatnya". (Lafazh riwayat Muslim) 


\begin{tabular}{|c|c|c|c|}
\hline $\begin{array}{c}\text { Teks } \\
\text { bahasa } \\
\text { sumber }\end{array}$ & $\begin{array}{l}\text { Penanda } \\
\text { kohesi }\end{array}$ & $\begin{array}{c}\text { Teks bahasa } \\
\text { sasaran }\end{array}$ & Analisis Penanda kohesi pronomina \\
\hline قال & $\begin{array}{l}\text { o dhamir } \\
\text { muttasil } \\
\text { mustatir }\end{array}$ & - & $\begin{array}{l}\text { فال mengacu pada Abu Hurairah, kata } \\
\text { ganti tunggal ه, dhamir muttasil } \\
\text { mustatir, persona } 3\end{array}$ \\
\hline عنه & ० & Nya & $\begin{array}{l}\text { - mengacu pada Abu Hurairah, kata } \\
\text { ganti tunggal هو, dhamir muttasil baris, } \\
\text { persona } 3\end{array}$ \\
\hline قال & $\begin{array}{l}\text { odhamir } \\
\text { muttasil } \\
\text { mustatir }\end{array}$ & Bersabda & $\begin{array}{l}\text { فال mengacu pada Rasulullah, kata ganti } \\
\text { tunggal ه ه هamir muttasil mustatir, } \\
\text { persona } 3\end{array}$ \\
\hline يسر & ي & - & $\begin{array}{l}\text { mengacu pada urusan orang, kata } \\
\text { ganti tunggal هو, dhamir muttasil } \\
\text { mustatir, persona } 3\end{array}$ \\
\hline يسّر & ي & - & $\begin{array}{l}\text { mengacu pada Allah, kata ganti } \\
\text { tunggal هو, dhamir } \text { muttasil mustatir, } \\
\text { persona } 3\end{array}$ \\
\hline ستره & 。 & - & $\begin{array}{l}\text { mengacu pada Allah, kata ganti } \\
\text { tunggal ه, dhamir muttasil baris, } \\
\text { persona } 3\end{array}$ \\
\hline أخيه & 。 & Nya & $\begin{array}{l}\text { - mengacu pada seorang mukmin, kata } \\
\text { ganti tunggal هو, dhamir muttasil baris, } \\
\text { persona } 3\end{array}$ \\
\hline سلك & هو & - & $\begin{array}{l}\text { سلك mengacu pada seorang mukmin, } \\
\text { kata ganti tunggal هو, dhamir muttasil } \\
\text { mustatir, persona } 3\end{array}$ \\
\hline 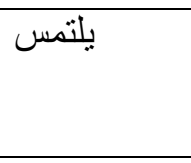 & ي & - & $\begin{array}{l}\text { mengacu pada seorang mukmin, kata } \\
\text { ganti tunggal هو, dhamir muttasil baris, } \\
\text { persona } 3\end{array}$ \\
\hline فيه & 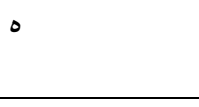 & Nya & $\begin{array}{l}\text { - mengacu pada jalan, kata ganti tunggal } \\
\text { ه dhamir muttasil mustatir, persona } 3\end{array}$ \\
\hline لاله باه & ० & Nya & $\begin{array}{l}\text { - mengacu pada seorang mukmin, kata } \\
\text { ganti tunggal ه, dhamir muttasil baris, } \\
\text { persona } 3 \\
\text { o mengacu pada jalan, kata ganti tunggal } \\
\text { ه, dhamir muttasil baris, persona } 3\end{array}$ \\
\hline 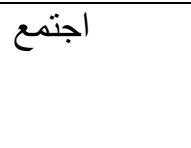 & - & Berkumpul & $\begin{array}{l}\text { اجتمع mengacu pada suatu kaum, kata } \\
\text { ganti jamak ه , dhamir muttasil baris, } \\
\text { persona } 3\end{array}$ \\
\hline 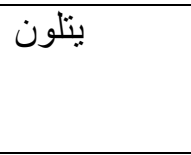 & واو & - & $\begin{array}{l}\text { واو mengacu pada mereka suatu kaum, } \\
\text { kata ganti jamak ه, dhamir muttasil } \\
\text { baris, persona } 3\end{array}$ \\
\hline و يتدارسونه & 。 & Nya & $\begin{array}{l}\text { - mengacu pada mereka suatu kaum, } \\
\text { kata ganti tunggal هو, dhamir muttasil } \\
\text { baris, persona } 3\end{array}$ \\
\hline
\end{tabular}




\begin{tabular}{|c|c|c|c|}
\hline $\begin{array}{c}\text { Teks } \\
\text { bahasa } \\
\text { sumber }\end{array}$ & $\begin{array}{c}\text { Penanda } \\
\text { kohesi }\end{array}$ & $\begin{array}{c}\text { Teks bahasa } \\
\text { sasaran }\end{array}$ & Analisis Penanda kohesi pronomina \\
\hline بينهم & هم & Mereka & $\begin{array}{l}\text { mengacu pada mereka suatu kaum, } \\
\text { kata ganti jamak ه, dhamir muttasil } \\
\text { baris, persona } 3\end{array}$ \\
\hline عليهم & هم & mereka & $\begin{array}{l}\text { \& mengacu pada mereka suatu kaum, } \\
\text { kata ganti jamak \$, dhamir muttasil } \\
\text { baris, persona } 3\end{array}$ \\
\hline غشيتهر & هم & - & $\begin{array}{l}\$ \text { mengacu pada mereka suatu kaum, } \\
\text { kata ganti jamak } \$ \text {, dhamir muttasil } \\
\text { baris, persona } 3\end{array}$ \\
\hline حفتهم & ه & - & $\begin{array}{l}\text { ه mengacu pada mereka suatu kaum, } \\
\text { kata ganti jamak \$, dhamir muttasil } \\
\text { baris, persona } 3\end{array}$ \\
\hline و ذ ذكر هم & ه & Mereka & $\begin{array}{l}\$ \text { mengacu pada mereka suatu kaum, } \\
\text { kata ganti jamak } \$ \text {, dhamir muttasil } \\
\text { baris, persona } 3\end{array}$ \\
\hline عنده & o & Nya & $\begin{array}{l}\text { - mengacu pada Allah, kata ganti } \\
\text { tunggal هو, dhamir muttasil baris, } \\
\text { persona } 3\end{array}$ \\
\hline عمله & o & Nya & $\begin{array}{l}\text { mengacu pada mereka suatu kaum, } \\
\text { kata ganti tunggal هو, dhamir muttasil } \\
\text { baris, persona } 3\end{array}$ \\
\hline 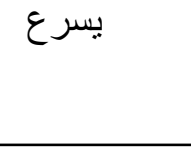 & ي & - & $\begin{array}{l}\text { mengacu pada derajat, kata ganti } \\
\text { tunggal ه, dhamir muttasil mustatir, } \\
\text { persona } 3\end{array}$ \\
\hline نسبه & 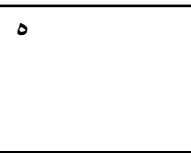 & Nya & $\begin{array}{l}\text { mengacu pada mereka suatu kaum, } \\
\text { kata ganti tunggal هو, dhamir muttasil } \\
\text { baris, persona } 3\end{array}$ \\
\hline
\end{tabular}

Data tersebut merupakan data yang menggunakan pengacuan persona yang direalisasikan melalui pronomina persona. Penerjemahan teks tersebut menggunakan teknik peminjaman yang dinaturalisasikan. Sebagai contohnya adalah dalam kata kiamat, akhirat, sakinah, rahmat dan malaikat. Teks tersebut menggunakan metode penerjemahan kata demi kata bahasa sumber dan sangat terikat pada tataran kata. Ideologi terjemahan yang digunakan adalah foreign-isasi.
Teknik, Metode, dan Ideologi Terjemahan pada Hadits 37

$$
\text { الحديث السابع والثلاثون }
$$

عن ابن عباس رضي الله عنهما عن رسول اله صلى

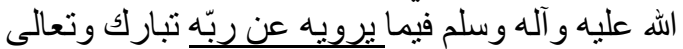

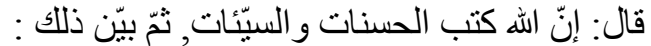
فمن همّ بحسنة فلم يعملها كتبهيا الله عنده حسنة كاملة,

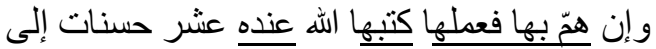

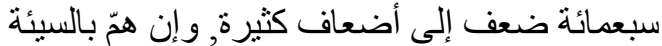

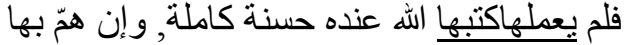

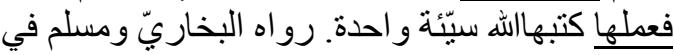
صحيحهما بهذه الحروف رواه البناري 
Terjemahan:

Dari Ibnu 'Abbas radhiallahu 'anhuma, dari Rasulullah shallallahu 'alaihi wa sallam, Beliau meriwayatkan dari Tuhannya, Tabaaraka wa ta'aala. Firman-Nya: "Sesungguhnya Allah telah menetapkan nilai kebaikan dan kejahatan, kemudian Dia menjelaskannya. Maka barangsiapa berniat mengerjakan kebaikan tetapi tidak dikerjakannya, Allah mencatatnya sebagai satu kebaikan yang sempurna.
Jika ia berniat untuk berbuat kebaikan lalu ia mengerjakannya, Allah mencatatnya sebagai 10 sampai 700 kali kebaikan atau lebih banyak lagi. Jika ia berniat melakukan kejahatan, tetapi ia tidak mengerjakannya, Allah mencatatkan padanya satu kebaikan yang sempurna. Jika ia berniat melakukan kejahatan lalu dikerjakannya, Allah mencatatnya sebagai satu kejahatan". (HR. Bukhari dan Muslim dalam Kitab Shahihnya dengan lafazh ini)

\begin{tabular}{|c|c|c|c|}
\hline $\begin{array}{c}\text { Teks } \\
\text { bahasa } \\
\text { sumber }\end{array}$ & $\begin{array}{l}\text { Penanda } \\
\text { kohesi }\end{array}$ & $\begin{array}{l}\text { Teks bahasa } \\
\text { sasaran }\end{array}$ & Analisis Penanda kohesi pronomina \\
\hline قال & $\begin{array}{l}\text { odhamir } \\
\text { muttasil } \\
\text { mustatir }\end{array}$ & Bersabda & $\begin{array}{l}\text { قال mengacu pada Rasulullah, kata } \\
\text { ganti tunggal هو, dhamir muttasil } \\
\text { mustatir, persona } 3\end{array}$ \\
\hline ي ليرويه & ي & - & $\begin{array}{l}\text { mengacu pada beliau Rasulullah, } \\
\text { kata ganti tunggal هو, dhamir muttasil } \\
\text { baris, persona } 3\end{array}$ \\
\hline ربّهـ & ○ & Nya & $\begin{array}{l}\text { ربّّ, ه mengacu pada Allah, kata ganti } \\
\text { tunggal هو, dhamir muttasil baris, } \\
\text { persona } 3\end{array}$ \\
\hline يعملها & ها & Nya & $\begin{array}{l}\text { smengacu pada pekerjaan, kata ganti } \\
\text { tunggal هو, dhamir muttasil baris, } \\
\text { persona } 3 \\
\text { ه mengacu pada kebaikan, kata ganti } \\
\text { tunggal هي, dhamir muttasil baris, } \\
\text { persona } 3\end{array}$ \\
\hline بيّن & - & Dia & $\begin{array}{l}\text { بيّن mengacu pada Dia "Rasulullah", } \\
\text { kata ganti tunggal هو, dhamir muttasil } \\
\text { mustatir, persona } 3\end{array}$ \\
\hline همّ بها & ها & - & $\begin{array}{l}\text { ه mengacu pada kebaikan, kata ganti } \\
\text { tunggal هي dhamir muttasil baris, } \\
\text { persona } 3\end{array}$ \\
\hline فعملها & ها & Nya & $\begin{array}{l}\text { ه mengacu pada kebaikan, kata ganti } \\
\text { tunggal هي dhamir muttasil baris, } \\
\text { persona } 3\end{array}$ \\
\hline كتبها & ها & Nya & $\begin{array}{l}\text { mengacu pada kebaikan, kata ganti } \\
\text { tunggal هي dhamir muttasil baris, } \\
\text { persona } 3\end{array}$ \\
\hline عنده & o & - & $\begin{array}{l}\text { - mengacu pada kata ganti tunggal هو, } \\
\text { dhamir muttasil baris, persona } 3\end{array}$ \\
\hline يعملها & هنا & $\mathrm{Di}$ & ي mengacu pada pekerjaan, kata \\
\hline
\end{tabular}




\begin{tabular}{|c|c|c|c|}
\hline $\begin{array}{c}\text { Teks } \\
\text { bahasa } \\
\text { sumber }\end{array}$ & $\begin{array}{c}\text { Penanda } \\
\text { kohesi }\end{array}$ & $\begin{array}{c}\text { Teks bahasa } \\
\text { sasaran }\end{array}$ & Analisis Penanda kohesi pronomina \\
\hline & & Nya & $\begin{array}{l}\text { ganti tunggal هو, dhamir muttasil } \\
\text { baris, persona } 3 \\
\text { ها mengacu pada kebaikan, kata ganti } \\
\text { tunggal هي هhamir muttasil baris, } \\
\text { persona } 3\end{array}$ \\
\hline كتبها & ها & Nya & $\begin{array}{l}\text { ه mengacu pada kejahatan, kata } \\
\text { ganti tunggal هي, dhamir muttasil } \\
\text { baris, persona } 3\end{array}$ \\
\hline 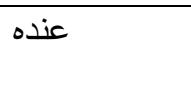 & o & - & $\begin{array}{l}\text { - mengacu pada kata ganti tunggal } \\
\text { dhamir muttasil baris, persona } 3\end{array}$ \\
\hline همّ بها & ها & - & $\begin{array}{l}\text { mengacu pada kejahatan, kata } \\
\text { ganti tunggal هي, dhamir muttasil } \\
\text { baris, persona } 3\end{array}$ \\
\hline فعملها & ها & Nya & $\begin{array}{l}\text { ه mengacu pada kejahatan, kata } \\
\text { ganti tunggal هي, dhamir muttasil } \\
\text { baris, persona } 3\end{array}$ \\
\hline كتبها & ها & Nya & $\begin{array}{l}\text { ه mengacu pada kejahatan, kata } \\
\text { ganti tunggal هي, dhamir muttasil } \\
\text { baris, persona } 3\end{array}$ \\
\hline
\end{tabular}

Data tersebut merupakan data yang menggunakan pengacuan persona yang direalisasikan melalui pronomina persona. Teks إنّ الله كتب innalla>ha katabaalchasana>ti wa-sayyia>ti yang artinya "sesungguhnya Allah telah menetapkan nilai kebaikan dan kejahatan" menggunakan teknik penerjemahan penambahan pada kata "nilai". Metode penerjemahan yang digunakan adalah komunikatif karena berupaya mengungkapkan makna konstektual bahasa sumber secara tepat. Ideologi yang digunakan adalah domestikasi karena tendensi ke bahasa sasaran.
Teknik, Metode, dan Ideologi Terjemahan pada Hadits 38

$$
\begin{aligned}
& \text { الحديث الثامن والثلاثون } \\
& \text { عن أبي هريرة - رضي الله عنه - قال : قال الي رسول }
\end{aligned}
$$

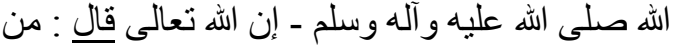

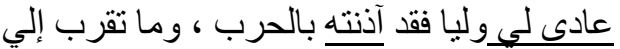

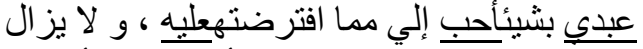

$$
\begin{aligned}
& \text { عبدي يتقرب إلي بالنو افل حتى أحبه ، فإذا أحبيته }
\end{aligned}
$$

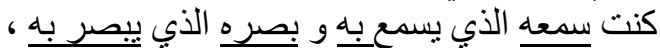

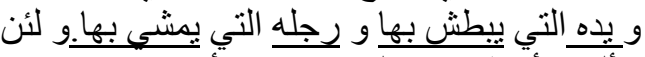

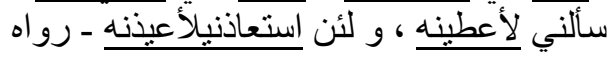

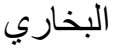

\section{Terjemahan:}

Dari Abu Hurairah radhiallahu 'anhu, ia berkata: bersabda Rasulullah shallallahu 'alaihi wa sallam "Sesungguhnya Allah ta'ala telah berfirman: 'Barang siapa memusuhi wali- $\underline{\mathrm{Ku}}$, maka sesungguhnya Aku menyatakan perang terhadapnya. Hamba-Ku senantiasa (ber-taqorrub) mendekatkan diri kepada-Ku dengan suatu (perbuatan) yang Aku sukai seperti bila ia melakukan yang fardhu yang Aku 
perintahkan kepadanya. Hamba-Ku senantiasa (ber-taqorrub) mendekatkan diri kepada-Ku dengan amalan-amalan sunah hingga Aku mencintainya. Jika $\underline{\text { Aku }}$ telah mencintainya, maka jadilah Aku sebagai pendengarannya yang ia gunakan untuk mendengar, sebagai penglihatannya yang ia gunakan untuk melihat, sebagai tangannya yang ia gunakan untuk memegang, sebagai kakinya yang ia gunakan untuk berjalan. Jika ia memohon sesuatu kepada-Ku, pasti Aku mengabulkannya dan jika ia

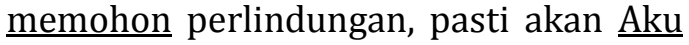
berikan kepadanya". (HR.Bukhari)

\begin{tabular}{|c|c|c|c|}
\hline $\begin{array}{c}\text { Teks } \\
\text { bahasa } \\
\text { sumber }\end{array}$ & $\begin{array}{c}\text { Penanda } \\
\text { kohesi }\end{array}$ & $\begin{array}{c}\text { Teks bahasa } \\
\text { sasaran }\end{array}$ & Analisis Penanda kohesi pronomina \\
\hline قال & هو & Ia berkata & $\begin{array}{l}\text { قال mengacu pada Abu Hurairah, kata } \\
\text { ganti tunggal هو, dhamir muttasil } \\
\text { mustatir, persona } 3\end{array}$ \\
\hline قال & $\begin{array}{l}\text { dhamir } \\
\text { muttasil } \\
\text { mustatir }\end{array}$ & Bersabda & $\begin{array}{l}\text { قال mengacu pada Rasulullah, kata ganti } \\
\text { tunggal ه ه \$ dhamir muttasil mustatir, } \\
\text { persona } 3\end{array}$ \\
\hline قال & $\begin{array}{l}\text { dhamir } \\
\text { muttasil } \\
\text { mustatir }\end{array}$ & Bersabda & $\begin{array}{l}\text { mengacu pada Allah, kata ganti } \\
\text { tunggal ه ه هamir muttasil mustatir, } \\
\text { persona } 3\end{array}$ \\
\hline لي & لي & $\mathrm{Ku}$ & 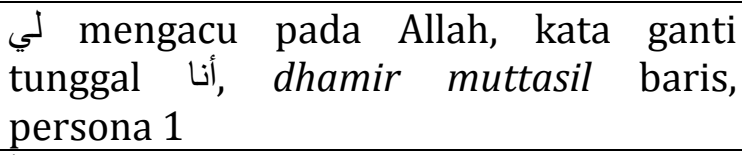 \\
\hline آذنتـــ & أ & $\begin{array}{l}\text { Aku } \\
\text { Nya }\end{array}$ & $\begin{array}{l}\text { I mengacu pada Allah, kata ganti tunggal } \\
\text { أنا, dhamir muttasil baris, persona } 1 \\
\text { o mengacu pada musuh, kata ganti } \\
\text { tunggal هو, dhamir muttasil baris, } \\
\text { persona } 3\end{array}$ \\
\hline عبدي & ي & $\mathrm{Ku}$ & 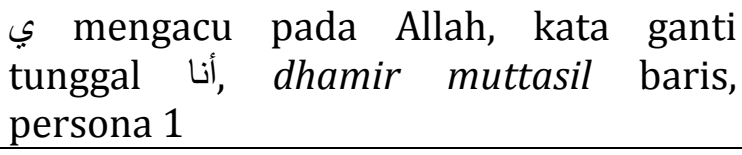 \\
\hline عليه & o & Nya & $\begin{array}{l}\text { - mengacu pada wali Allah, kata ganti } \\
\text { tunggal ه, dhamir muttasil baris, } \\
\text { persona } 3\end{array}$ \\
\hline أحبه & أ & $\begin{array}{l}\text { Aku } \\
\text { Nya }\end{array}$ & $\begin{array}{l}\text { I mengacu pada Allah, kata ganti tunggal } \\
\text { ه, dhamir muttasil baris, persona } 3 \\
\text { o mengacu pada wali Allah, kata ganti } \\
\text { tunggal هو, dhamir muttasil baris, } \\
\text { persona } 3\end{array}$ \\
\hline أحبيته & $ت$ & $\begin{array}{l}\text { Aku } \\
\text { Nya }\end{array}$ & $\begin{array}{l}\because \text { mengacu pada Allah, kata ganti } \\
\text { tunggal ه, dhamir muttasil baris, } \\
\text { persona } 3 \\
\text { o mengacu pada wali Allah, kata ganti } \\
\text { tunggal هو, dhamir muttasil baris, } \\
\text { persona } 3\end{array}$ \\
\hline
\end{tabular}




\begin{tabular}{|c|c|c|c|}
\hline $\begin{array}{c}\text { Teks } \\
\text { bahasa } \\
\text { sumber }\end{array}$ & $\begin{array}{c}\text { Penanda } \\
\text { kohesi }\end{array}$ & $\begin{array}{l}\text { Teks bahasa } \\
\text { sasaran }\end{array}$ & Analisis Penanda kohesi pronomina \\
\hline كنت & $ت$ & Aku & $\begin{array}{l}\begin{array}{l}* \text { mengacu } \\
\text { tunggal أنا, }\end{array} \text { dhamir muttasil baris, } \\
\text { persona 1 }\end{array}$ \\
\hline سمعه & o & Nya & $\begin{array}{l}\text { - mengacu pada wali Allah, kata ganti } \\
\text { tunggal هو, dhamir muttasil baris, } \\
\text { persona } 3\end{array}$ \\
\hline بصره & o & Nya & $\begin{array}{l}\text { - mengacu pada wali Allah, kata ganti } \\
\text { tunggal ه dhamir muttasil baris, } \\
\text { persona } 3\end{array}$ \\
\hline يده & o & Nya & $\begin{array}{l}\text { - mengacu pada wali Allah, kata ganti } \\
\text { tunggal هو, dhamir muttasil baris, } \\
\text { persona } 3\end{array}$ \\
\hline يبطش بها & ها & - & $\begin{array}{l}\text { mengacu pada tangan, kata ganti } \\
\text { tunggal هو, dhamir muttasil baris, } \\
\text { persona } 3 \\
\text { ه mengacu pada kata ganti tunggal هي, } \\
\text { dhamir muttasil baris, persona } 3\end{array}$ \\
\hline رجله & o & Nya & $\begin{array}{l}\text { - mengacu pada wali Allah, kata ganti } \\
\text { tunggal ه dhamir muttasil baris, } \\
\text { persona } 3\end{array}$ \\
\hline يمشي بها & ها & Ia & $\begin{array}{l}\text { ي mengacu pada kaki, kata ganti tunggal } \\
\text { ه dhamir muttasil baris, persona } 3 \\
\text { ها mengacu pada kata ganti tunggal } \\
\text { dhamir muttasil baris, persona 3 }\end{array}$ \\
\hline لأأعطينه & i & $\begin{array}{l}\text { Aku } \\
\text { Nya }\end{array}$ & $\begin{array}{l}\text { Í mengacu pada Allah, kata ganti tunggal } \\
\text { أنا, dhamir muttasil baris, persona } 1 \\
\text { - mengacu pada permohonan, kata ganti } \\
\text { tunggal هو, dhamir muttasil baris, } \\
\text { persona } 3\end{array}$ \\
\hline استعاذني & ي & $\mathrm{Ku}$ & $\begin{array}{l}\text { mengacu pada Allah, kata ganti } \\
\text { tunggal أنا, dhamir muttasil baris, } \\
\text { persona 1 }\end{array}$ \\
\hline لأعيذنه & أ & $\begin{array}{l}\text { berikan } \\
\text { kepada } \\
\text { nya }\end{array}$ & $\begin{array}{l}\text { Í mengacu pada Allah, kata ganti tunggal } \\
\text { أنا, dhamir muttasil baris, persona } 1 \\
\text { o mengacu pada wali Allah, kata ganti } \\
\text { tunggal هو, dhamir muttasil baris, } \\
\text { persona } 3\end{array}$ \\
\hline
\end{tabular}


Data tersebut merupakan data yang menggunakan pengacuan persona yang direalisasikan melalui pronomina persona. Teks tersebut menggunakan teknik penerjemahan peminjaman yang dinaturalisasikan, misalnya pada kata waliku, bertaqarrub, fardhu, dan sunnah. Terjemahan itu menggunakan metode penerjemahan kata demi kata. Karena mempertahankan bahasa sumber, ideologi terjemahan tersebut adalah ideologi foreignisasi.
Teknik, Metode, dan Ideologi Terjemahan pada Hadits 39

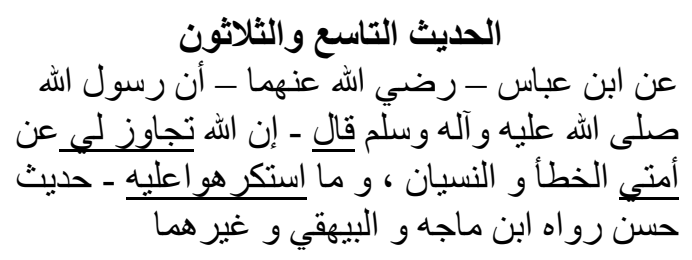

\section{Terjemahan:}

Dari Ibnu Abbas radhiyallahu anhuma, sesungguhnya Rasululloh shallallahu 'alaihi wa sallam telah bersabda: " Sesungguhnya Allah telah mema'afkan kesalahan-kesalahan umat-Ku yang tidak disengaja, karena lupa dan yang dipaksa melakukannya" (HR. Ibnu Majah, Baihaqi dll, hadits hasan).

\begin{tabular}{|c|c|c|c|}
\hline $\begin{array}{c}\text { Teks } \\
\text { bahasa } \\
\text { sumber }\end{array}$ & $\begin{array}{c}\text { Penanda } \\
\text { kohesi }\end{array}$ & $\begin{array}{l}\text { Teks bahasa } \\
\text { sasaran }\end{array}$ & Analisis Penanda kohesi pronomina \\
\hline ق قال & $\begin{array}{l}\text { dhamir } \\
\text { muttasil } \\
\text { mustatir }\end{array}$ & Bersabda & $\begin{array}{l}\text { قال mengacu pada Rasulullah, kata ganti } \\
\text { tunggal هو, dhamir muttasil mustatir, } \\
\text { persona } 3\end{array}$ \\
\hline لي & ي & - & $\begin{array}{l}\text { أنًا, mengacu pada Allah, kata ganti tunggal } \\
\text { أن muttasil baris, persona } 1\end{array}$ \\
\hline أمتي & ي & $\mathrm{Ku}$ & $\begin{array}{l}\text { ئil mengacu pada Allah, kata ganti tunggal } \\
\text { أنا dhamir muttasil baris, persona } 1\end{array}$ \\
\hline ما استكر هو ا & واو & - & $\begin{array}{l}\text { واو mengacu pada umat, kata ganti jamak } \\
ه \text {, dhamir muttasil baris, persona } 3\end{array}$ \\
\hline عليه & ○ & Nya & $\begin{array}{l}\text { mengacu pada kesalahan, kata ganti } \\
\text { tunggal هو, dhamir muttasil baris, persona } \\
3\end{array}$ \\
\hline
\end{tabular}

Data tersebut merupakan data yang menggunakan pengacuan persona yang direalisasikan melalui pronomina persona. Teks tersebut memiliki teknik peminjaman pada kata umatku. Terjemahan itu menggunakan metode penerjemahan kata demi kata, sehingga ideologi yang digunakan adalah ideologi foreign-isasi.
Teknik, Metode, dan Ideologi Terjemahan pada Hadits 40

$$
\text { الحديث العربعون }
$$

عن ابن عمر رضي الله عنهما قال: أخذ رسول الهـ صلى الله عليه و آله وسلم بمنكبي, فقالِ: كن في الدنيا

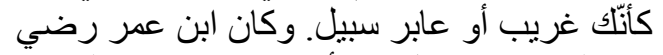

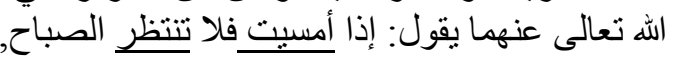
و إذا أصبحت فلا تنتظر المساء, وخذ من صحتئي لمرضك, ومن حياتك لموتلك. رو اه البخاري لئي 
Terjemahan:

Dari Ibnu Umar radhiallahu 'anhuma, ia berkata: "Rasulullah shallallahu 'alaihi wa sallam memegang pundakku, lalu bersabda: Jadilah engkau di dunia ini seakan-akan sebagai orang asing atau pengembara. Lalu Ibnu Umar radhiyallahu anhuma berkata: "Jika engkau di waktu sore, maka janganlah engkau menunggu pagi dan jika engkau di waktu pagi, maka janganlah menunggu sore dan pergunakanlah waktu sehatmu sebelum kamu sakit dan waktu hidupmu sebelum kamu mati”. (HR. Bukhari)

\begin{tabular}{|c|c|c|c|}
\hline $\begin{array}{l}\text { Teks } \\
\text { bahasa } \\
\text { sumber }\end{array}$ & $\begin{array}{c}\text { Penanda } \\
\text { kohesi }\end{array}$ & $\begin{array}{c}\text { Teks } \\
\text { bahasa } \\
\text { sasaran }\end{array}$ & Analisis Penanda kohesi pronomina \\
\hline قال & $\begin{array}{l}\text { os dhamir } \\
\text { muttasil } \\
\text { mustatir }\end{array}$ & ia berkata & $\begin{array}{l}\text { قال mengacu pada Ibnu Umar, kata ganti } \\
\text { tunggal هو, dhamir muttasil mustatir, } \\
\text { persona } 3\end{array}$ \\
\hline بمنكبي & ي & $\mathrm{Ku}$ & $\begin{array}{l}\text { mengacu pada Ibnu Umar, kata ganti } \\
\text { tunggal أنا, dhamir muttasil baris, persona } 1\end{array}$ \\
\hline فقال & $\begin{array}{l}\text { dhamir } \\
\text { muttasil } \\
\text { mustatir }\end{array}$ & Bersabda & $\begin{array}{l}\text { mengacu pada Rasulullah, kata ganti tunggal } \\
ه, \text { dhamir muttasil mustatir, persona } 3\end{array}$ \\
\hline 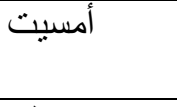 & $ت$ & Engkau & $\begin{array}{l}ت \text { mengacu pada Ibnu Umar, kata ganti } \\
\text { tunggal هو, dhamir muttasil baris, persona } 2\end{array}$ \\
\hline ت تنتظر & $ت$ & engkau & $\begin{array}{l}ت \text { mengacu pada Ibnu Umar, kata ganti } \\
\text { tunggal ه, dhamir muttasil baris, persona } 2\end{array}$ \\
\hline أصبحت & ت & Engkau & $\begin{array}{l}ت \text { mengacu pada Ibnu Umar, kata ganti } \\
\text { tunggal } ه \text {, dhamir muttasil baris, persona } 2\end{array}$ \\
\hline ت ت تنظر & ت & engkau & $\begin{array}{l}ت \text { mengacu pada Ibnu Umar, kata ganti } \\
\text { tunggal ه, dhamir muttasil baris, persona } 2\end{array}$ \\
\hline صحتك & ك & $\mathrm{Mu}$ & $\begin{array}{l}\text { 5) mengacu pada Ibnu Umar, kata ganti } \\
\text { tunggal أنت, dhamir muttasil baris, persona } 2\end{array}$ \\
\hline ل لمرضك & 5 & kamu & $\begin{array}{l}\text { 5) mengacu pada Ibnu Umar, kata ganti } \\
\text { tunggal أنت, dhamir muttasil baris, persona } 2\end{array}$ \\
\hline حياتك & ك5 & $\mathrm{Mu}$ & $\begin{array}{l}\text { 5) mengacu pada Ibnu Umar, kata ganti } \\
\text { tunggal أنت, dhamir muttasil baris, persona } 2\end{array}$ \\
\hline
\end{tabular}

Data tersebut merupakan data yang menggunakan pengacuan persona yang direalisasikan melalui pronomina persona. Teks tersebut menggunakan teknik penerjemahan literal pada kalimat كن في الدنيا kun fi> ad-dunya>. Teks itu diterjemahkan menjadi "jadilah engkau di dunia ini". Terjemahan tersebut menggunakan metode penerjemahan kata demi kata sehingga termasuk ideologi foreignisasi.

\section{SIMPULAN}

Berdasarkan hasil pembahasan tersebut diperoleh kesimpulan sebagai berikut. Pertama, penanda kohesi yang digunakan dalam menerjemahkan hadits Arba'in ke 31-40 adalah pengacuan persona melalui pronomina persona. Kedua, teknik penerjemahan yang digunakan 
dalam menerjemahkan hadits Arba'in ke 31-40 adalah teknik penerjemahan literal, peminjaman, penambahan dan deskripsi. Ketiga, metode penerjemahan yang digunakan dalam menerjemahkan hadits Arba'in ke 31-40 adalah metode penerjemahan kata demi kata, metode penerjemahan komunikatif dan metode penerjemahan bebas. Keempat, ideologi penerjemahan yang digunakan dalam menerjemahkan hadits Arba'in ke 31-40 adalah ideologi foreignisasi dengan jumlah 7 dan ideologi domestikasi dengan jumlah 3.

\section{DAFTAR PUSTAKA}

Amalia, F.(2007). "Peningkatan Kemampuan Menerjemahkan Bahasa Perancis ke dalam Bahasa Indonesia Melalui Model Penerjemahan PedagosisProfesional". Tesis, Fakultas Pendidikan Bahasa dan Seni, Universitas Pendidikan Indonesia, Bandung

Hatim, B dan I. Manson. (1997). The Translator as communicator. London and New York: Roudledge
Huda, N (2015). Mudah Belajar Bahasa Arab. Jakarta: Penerbit Amzah Machali, R. (2009). Pedoman bagi Penerjemah. Bandung: Kaifa PT. Mizan Pustaka.

Molina, L \& Hurtado, A. (2002). "Translation Techniques Revisited: A Dynamic and Functionalist Approach". META, XLVII, 4, 2004

Sudaryanto. (1993). Metode Dan Aneka Teknik Analisis Bahasa. Yogyakarta: Duta Wacana University Press

Sumarlam. (2005). Teori dan Praktik Analisis Wacana. Surakarta: Pustaka Cakra

Supana. (2012). "Kajian Terjemahan Penanda Kohesi pada Novel Wings karya Danielle Steel ke dalam Bahasa Indonesia". disertasi, Program Pascasarjana Universitas Sebelas Maret Surakarta, Surakarta

Sutopo, H.B. (2006). Penelitian Kualitatif: Dasar Teori dan Terapannya dalam Penelitian. Surakarta: Universitas Sebelas Maret Press

Venuti, L. (1995). The Translator's Invisibility: A History of Translation. London and New York: 